\title{
Experimental determination of the effects of cattle stocking density and grazing period on forest regeneration on a subalpine wood pasture
}

\author{
Andrea C. MAYER ${ }^{\mathrm{a}}$, Beda L. ESTERMANN ${ }^{\mathrm{b}}$, Veronika STÖCKLI ${ }^{\mathrm{a}}$, \\ Michael KREUZER ${ }^{b *}$
}

\author{
a WSL, Swiss Federal Institute for Snow and Avalanche Research (SLF), Flüelastrasse 11, \\ CH-7260 Davos Dorf, Switzerland \\ ${ }^{b}$ Institute of Animal Science, Animal Nutrition, Swiss Federal Institute of Technology (ETH) Zurich, \\ ETH centre/LFW, CH-8092 Zurich, Switzerland
}

(Received 15 May 2003; accepted 4 April 2005)

\begin{abstract}
The influence of cattle stocking density and the length of the grazing period on the extent of tree damage on subalpine wood pastures was assessed. An experiment was carried out on four adjoining fields, grazed by zero, three, six and nine heifers. The fields were grazed until herbage resources were exploited. Spruce seeds were seeded, spruce saplings (Picea abies (L.) Karst. (average height of $14 \mathrm{~cm}$ ) as well as young spruces, larches (Larix decidua Miller) and rowans (Sorbus aucuparia L.) of $42 \mathrm{~cm}$ height were planted. The experimental site was situated at $1900 \mathrm{~m}$ a.s.l.; $20 \%$ of the area was forest. Browsing and other damage on planted spruce saplings and young spruces, larches and rowans were recorded. The germination rate of spruce seeds was recorded and the survival rate of the seedlings germinated was analysed. The heifers spent around 30\% of the time under the tree canopies, both for resting and grazing, instead of the expected $20 \%$ based on the relative forest cover. Since the herbage quality was found to be similar in the forest and on the open pasture and since there was no effect of stocking density on herbage intake and digestibility as assessed in the first week of the experiment, the effects on the trees were considered independent from herbage quality. Grazing at high stocking densities enhanced the germination of spruce seedlings. Rowan was browsed most frequently, depending on stocking density and grazing period. Also larch was browsed frequently. With increasing grazing time, even spruces of $14 \mathrm{~cm}$ and $42 \mathrm{~cm}$ height were frequently browsed, but there was no clear relationship to stocking density. The observations showed that individual animals that have developed a specific preference for spruce needles may play a decisive role in the extent of browsing on spruce. In conclusion, guidelines for a sustainable use of subalpine wood pastures require restrictions either in stocking density or in the length of the grazing period or in both.
\end{abstract}

agroforestry / alkane / silvopastoral systems / tree browsing

Résumé - Détermination expérimentale des effets de la densité du bétail et de la durée de pacage sur la régénération des forêts dans un système sylvopastoral. Cette étude a pour but d'évaluer l'influence de la densité du bétail et de la durée de pacage sur l'étendue des dommages occasionnés

* Corresponding author: michael.kreuzer@inw.agrl.ethz.ch 
aux arbres situés dans les pâturages boisés. Pour cette expérience, un pâturage a été divisé en 4 sections pâturées par $0,3,6$ et 9 génisses respectivement. Ces pacages ont été pâturés jusqu'à l'exploitation totale de leurs ressources. Des graines d'épicéas ont été semées et de jeunes épicéas (hauteur moyenne de $14 \mathrm{~cm}$ ) ainsi que des mélèzes et des sorbiers de $42 \mathrm{~cm}$ ont été plantés. La parcelle utilisée est située à une altitude de $1900 \mathrm{~m}$ et couverte à $20 \%$ par de la forêt. L'abroutissement et les autres dégâts occasionnés sur les semis d'épicéas ainsi que sur les jeunes épicéas, mélèzes et sorbiers ont été systématiquement répertoriés. Le taux de germination des graines d'épicéa a été établi et le taux de survie des semis a été analysé. Il a été observé que les génisses ont passé environ $30 \%$ du temps sous les arbres pour se reposer ou pour brouter au lieu des $20 \%$ attendus par rapport au taux de couverture forestière. La position et l'activité des génisses ont été consignées, ainsi que l'incorporation et la digestibilité de la pâture. Étant donné que la qualité de la pâture était similaire dans la forêt et dans le pâturage et que la densité des génisses n'a pas eu d'effet sur la digestibilité et l'incorporation de la pâture, les effets sur les arbres ont été étudiés indépendamment de la qualité de la pâture. Le pacage avec une densité élevée de bétail augmente la germination des épicéas. Le sorbier est le plus souvent abrouti suivant la densité des génisses et la longueur de la période de pâture. Les mélèzes ont également été fréquemment abrouti. Avec une augmentation de la durée de pâture, les jeunes épicéas (de $14 \mathrm{~cm}$ et de $42 \mathrm{~cm}$ de hauteur) ont également été broutés, mais la relation entre la densité des génisses et l'abroutissement de ceux-ci n'est pas claire. Certains animaux ont développé une préférence spécifique pour les aiguilles des épicéas, ce qui peut avoir une grosse influence sur les dommages occasionnés sur ceux-ci. En conclusion, une utilisation durable des forêts subalpines requiert des restrictions concernant la densité du bétail et la durée de la période de pacage.

agroforesterie / alcane / système sylvopastoral / abroutissement

\section{INTRODUCTION}

Forest grazing is probably one of the oldest forms of land-use [13] and has a long tradition in Switzerland [15]. In an inventory completed in 1999 [7], about $15 \%$ of the mountain forests in Switzerland were found to be grazed by domestic animals, mainly by cattle. Although agroforestry is becoming increasingly common [13], there are attempts to reduce or even prohibit traditional forest grazing in the Alps [8]. The influence of cattle grazing on the regeneration of subalpine forests has been the subject of lively debates over the past decades, but few exact data are available to substantiate any of the opinions, and thus conflicting views continue to exist. The main argument raised against forest grazing is that the activity of the animals may lead to a decelerated regeneration of the forests, resulting from the browsing and trampling of young trees [8]. This, it is argued, in the long term could endanger the protective function of the forests against natural hazards [43], among them avalanches. In one of the few scientific studies dealing with the effects of grazing on subalpine forests, Liss [28] suggested that cat- tle grazing does not severely impair the regeneration of montane and subalpine forests and that wild ungulates typically cause more browsing damage on young trees than cattle do. Our previous field studies on a variety of established subalpine wood pastures [33] identified important factors influencing the frequency of browsing of young trees by cattle, particularly stocking density and grazing period, but also herbage quality and available herbage quantity in relation to the requirements of the cattle. However, it was not possible in that study to clearly differentiate between the effects of stocking density and grazing period. Additionally the study only investigated trees taller than $0.3 \mathrm{~m}$. Another still unsolved question is whether cattle grazing really enhances the germination of tree seeds as claimed by several authors [e.g., 19].

The objective of the present experiment was to investigate - under controlled conditions - the germination rate of spruce (Picea abies (L.) Karst.) seeds and the damage to young spruces, larches (Larix decidua Miller) and rowans (Sorbus aucuparia L.) caused by the breaking of lateral shoots, browsing and trampling by 
cattle, taking into account herbage availability, quality and consumption. Adjoining fields of the same size ( 0.5 hectare) were established and trees were seeded and planted systematically. A grazing schedule was established that enabled the differentiation between the effects of stocking density and length of the grazing period.

\section{MATERIALS AND METHODS}

\subsection{Experimental site}

The experiment was conducted on an Alpine pasture situated at $1970 \mathrm{~m}$ a.s.l. next to the lake Lai da Palpuogna (46³4'30', latitude $\mathrm{N}$; 9 $47^{\prime} 10^{\prime}$ ' longitude E) in the Swiss canton Grisons. Approximately $20 \%$ of the area was covered with mature trees of the species Norway spruce, European larch and stone-pine (Pinus cembra L.). The herbage was diverse which is typical for this altitude when not treated with mineral fertiliser. In detail, 75 different plant species were found, including 48 forbs, 17 grasses, 3 legumes and 7 shrubs.

\subsection{Experimental fields and grazing schedule}

The pasture site was separated into four fields of 0.51 hectare each. This relatively small field size was chosen to allow direct observations of all cattle at once. Furthermore, high grazing intensities could be achieved with short grazing periods. These fields were fenced in a way that completely excluded access by wild ungulates. One of these fields was left ungrazed, while the other three fields were stocked with three, six and nine one-year old heifers, respectively. In order to avoid a systematic bias from local gradients, the allocation of the four stocking densities to the four adjoining fields was done randomly. The limited size of the research area did not allow the replication of the different stocking densities. The heifers were crossbreeds from Brown Swiss or Holstein dams and Blond d'Aqui- taine, Angus or Limousin sires. The actual grazing intensities were $0,2.8,5.5$ and 7.9 livestock units (LU) $\cdot \mathrm{ha}^{-1}$ for the fields investigated. The potential grazing intensities, i.e. the average intensity when seen over the complete potential grazing period, ranged from $0.09 \mathrm{LU} \cdot \mathrm{ha}^{-1}$ on Field 1 when grazing only for 3 days to $1.23 \mathrm{LU} \cdot \mathrm{ha}^{-1}$ on Field 3 at the end of the grazing period (Tab. I).

During the 13 days before the experiment started, the experimental groups of three, six and nine heifers grazed three separate pastures, which were situated close to the experimental fields and had a species composition similar to that of the experimental fields. The experiment started on 25 June 2001. In the experiment, all fields were deliberately grazed until being as completely exploited as possible. Complete exploitation was confirmed by the visual appearance of the fields after grazing. This grazing schedule implied that grazing periods were decreasing with increasing stocking density. According to the maximum exploitation rate of the herbage, the Fields 1 , 2 and 3 were grazed for 26, 18 and 14 days, respectively. The exploitation rates of the herbage differed from $50 \%$ to $70 \%$, with $65 \%$ having been found to be more or less equivalent to a complete exploitation of all herbaceous material on other wood pastures [33] thus taking into account that a certain proportion of herbage is always lost by trampling and contamination with excreta. These losses were more pronounced in the prolonged grazing period with low stocking densities resulting in a lower actual exploitation rate on Field 1 compared to Fields 2 and 3 .

Although the different stocking densities were not repeated, the approach nevertheless presents an advantage over traditional methods following the effects on long ago established sites. Firstly, the experimental set-up allowed following a linear gradient on both stocking density and the product of livestock units and grazing days (see regression approach applied in the figures). 
Table I. Stocking characteristics, availability and exploitation of herbage biomass (means \pm S.D.).

\begin{tabular}{|c|c|c|c|c|}
\hline & Field 0 & Field 1 & Field 2 & Field 3 \\
\hline \multicolumn{5}{|l|}{ Stocking characteristics } \\
\hline Field size (ha) & 0.51 & 0.51 & 0.51 & 0.51 \\
\hline Heifers (number) & 0 & 3 & 6 & 9 \\
\hline \multicolumn{5}{|l|}{ Live weight $(\mathrm{kg})$} \\
\hline all heifers & - & $287 \pm 81$ & $283 \pm 68$ & $269 \pm 75$ \\
\hline heifers which received capsules & - & $287 \pm 81$ & $302 \pm 42$ & $280 \pm 37$ \\
\hline \multicolumn{5}{|l|}{ Livestock units (LU) $\cdot \mathrm{ha}^{-1}$} \\
\hline according to current regulations ${ }^{1}$ & 0 & 2.4 & 4.7 & 7.1 \\
\hline actually $^{2}$ & 0 & 2.8 & 5.5 & 7.9 \\
\hline \multicolumn{5}{|l|}{ Grazing days $\times$ actual $L U \cdot h a^{-1}$} \\
\hline 3 days & - & 8.4 & 16.7 & 23.7 \\
\hline 7 days & - & 19.7 & 38.9 & 55.4 \\
\hline 14 days & - & 39.3 & 77.8 & 110.8 \\
\hline 18 days & - & 50.6 & 100.0 & - \\
\hline 26 days & - & 73.1 & - & - \\
\hline \multicolumn{5}{|l|}{$\begin{array}{l}\text { Potential grazing density }{ }^{3} \\
\left(\text { Potential grazing days } \cdot L U \cdot h a^{-1}\right)\end{array}$} \\
\hline 3 days & - & 0.09 & 0.19 & 0.26 \\
\hline 7 days & - & 0.22 & 0.43 & 0.62 \\
\hline 14 days & - & 0.44 & 0.86 & 1.23 \\
\hline 18 days & - & 0.56 & 1.11 & \\
\hline 26 days & - & 0.81 & & \\
\hline \multicolumn{5}{|l|}{ Herbage biomass } \\
\hline Availability $\left(\mathrm{kg} \mathrm{DM} \cdot \mathrm{ha}^{-1}\right)$ & 2800 & 2200 & 1800 & 2500 \\
\hline \multicolumn{5}{|l|}{ Exploitation by heifers $(\%)^{4}$} \\
\hline after 3 days & - & 5 & 10 & 13 \\
\hline after 7 days & - & 12 & 24 & 30 \\
\hline after 14 days & - & 24 & 48 & 60 \\
\hline after 18 days & - & 33 & 67 & - \\
\hline after 26 days & - & 46 & - & - \\
\hline
\end{tabular}

${ }^{1} 0.4$ LU per one-year old heifer [5].

${ }^{2}$ Equivalent to $600 \mathrm{~kg}$ of live weight [5].

${ }^{3}$ Potential livestock density = Grazing days $\cdot$ actual LU $\cdot h^{-1}$ divided by 90; i.e., based on 90 potential grazing days given by Dietl et al. [9] for (sub)alpine pastures; potential livestock density is lower when grazing over the complete grazing period is assumed [33].

${ }^{4}$ Estimated on the basis of available herbage and measured intakes (cf. Tab. IV).

Secondly, by comparing the results obtained after the same grazing period $(3,7$ and 14 days), we evaluated the exclusive effect of the stocking density. Finally, comparing the situation at the respective end-points demonstrates whether, at the same overall grazing intensity (product of grazing days and livestock units per hectare), the duration of 
grazing has an effect or whether other factors still have a major importance. Table I gives the product of grazing days and LU per hectare (grazing intensity) for the different time periods of tree examination. Table I also shows the herbage initially available on the different fields as calculated from biomass samples (cf. 2.4) cut directly before the grazing period. Fields 1 , 2 and 3 were subjected to grazing by the same number of heifers again for one week, from 21 to 28 August 2001.

\subsection{Sample trees}

On 3 October 2000, on each field, 19 barerooted spruce saplings (T2) with an average height of $14 \pm 2 \mathrm{~cm}$, purchased from a tree nursery (Kantonaler Forstgarten, Rodels, Switzerland), were planted. Thirteen saplings were randomly distributed in the open area $(68 \%)$ and six saplings were randomly distributed under the canopy of old trees $(32 \%)$. This means that more saplings were planted under the canopy of old trees than would be equivalent to the percentage of forest area $(20 \%)$. This ensured a sufficient sample size for the forest area. After planting, the height of the saplings and the length of the apical shoot of the previous and current year were measured. Additionally, the healthy lateral shoots were counted. At the same time, six groups of containerised young trees (T3), each group consisting of three spruces, three larches and three rowans, were planted on each field on plots of approximately $2 \mathrm{~m}^{2}$ size on a grid of 29 by $29 \mathrm{~m}$. Two of the plots on each field were randomly distributed under the canopy of old trees $(33 \%)$, and four plots were randomly distributed in the open area $(67 \%)$ similarly as T2 were distributed. The larches and rowans were again purchased from Kantonaler Forstgarten, the spruces were purchased from another tree nursery (Zoja, Klosters, Switzerland). These spruces, larches and rowans had average heights of $46 \pm 7 \mathrm{~cm}, 42 \pm 7 \mathrm{~cm}$ and $38 \pm 12 \mathrm{~cm}$ and average diameters of $17 \pm 4 \mathrm{~mm}, 7 \pm 2 \mathrm{~mm}$, $7 \pm 1 \mathrm{~mm}$, respectively. This was equivalent to height-diameter ratios of $2.8 \pm 0.7,3.4 \pm$ 1.6 and $4.3 \pm 1.6$. The condition of the young trees was assessed and their height and apical shoot length was measured in the same way as on the saplings. In addition, in the spruces and larches, the lengths of the apical and three lateral shoots, the latter being marked, were measured. In the rowans, however, the healthy lateral shoots were only counted, since marking proved to be impossible. One day before the start of the grazing period in June 2001, we seeded 400 Norway spruce seeds (produced by WSL, Birmensdorf, Switzerland) each on eight plots of 40 by $40 \mathrm{~cm}$ on each field. Three of the plots on each field were arranged under the canopy of mature trees, while the other five plots were located in the open area.

\subsection{Observation of cattle behavioural pattern}

The space use and activity pattern of the heifers on the different fields were observed during the first week of the experiment, starting on 25 June 2001. This was done 15 times a day, at 05.00, 06.30, 07.00, 09.30, 10.00, 10.30, 13.00, 13.30, 14.00, $16.30,17.00,17.30,20.00,20.30$ and $21.00 \mathrm{~h}$. This time schedule was developed in order to be able to group the observations for distinct day times, i.e. early and late morning, early and late afternoon, and evening. At each point of time, the number of heifers staying on the open pasture and under the canopies of the old trees was registered. Additionally, the momentary activity (grazing or resting) was recorded for each individual. Since all fields were visible from one place, one complete observation of the locations and activities of all heifers lasted for a few minutes only.

\subsection{Measurement of herbage intake and digestibility}

Intake and digestibility of the herbage were determined using the double alkane indicator technique in the first week of the 
experiment. A detailed description of the application of this technique in studies on subalpine wood pastures is provided by Mayer et al. [33], based on previous outlines and experiences $[4,5,12,32]$. Three heifers of each field with similar average live weight as the complete group (Tab. I) were selected for these detailed measurements. Representative herbage samples were collected five times a day for one hour $(06.00$ to $07.00,09.30$ to $10.30,13.00$ to 14.00 , 16.30 to 17.30 and 20.00 to $21.00 \mathrm{~h}$ ). Herbage samples from the open pastures and under the canopies of old trees were collected and analysed separately. The composition and amount of the standing herbage was assessed by collecting representative samples of the biomass cut approximately $3 \mathrm{~cm}$ above ground as recommended by Estermann et al. [12] on eight 20 by $20 \mathrm{~cm}$ squares per field close to randomly selected spruce saplings. Five squares were situated on the open pasture, three squares were located in the forest. These biomass samples were taken one day before the start of grazing. In order to be able to compare the herbage offered and the herbage consumed, the herbage samples were obtained from still ungrazed patches after 0.5 and after 1 week of grazing. Additional samples of the herbage offered were collected after 2, 3 and 4 weeks of grazing, respectively. The average of all six dates of herbage sampling was used to compare the nutrient contents of the herbage on the open pasture and under tree canopy. Herbage and faeces analysis for contents of nutrients and alkanes was done as previously described [33].

It was assumed that the herbage intake measured during the first experimental week was representative for the whole grazing period on the respective field. This allowed the calculation of herbage exploitation by subtracting the herbage consumed from the herbage available, which had been calculated from the biomass samples taken before the grazing period. However, it has to be considered that this approach does not account for biomass re-growth during the grazing period.

\subsection{Determination of tree damage and germination rates}

The effects of grazing on tree condition were determined 3, 7, 14, 18 (Fields 1 and 2 only) and 26 (Field 1 only) days after the start of the first grazing in June. For each planted tree it was registered whether it was still alive, whether the apical shoot or a lateral shoot had been browsed and whether other damage, such as broken lateral shoots, trampling marks or fraying scars had occurred. The extent of lateral shoot browsing was assessed using an intensity scale consisting of four classes: 0 to $20 \%, 20$ to $40 \%, 40$ to $60 \%$ and more than $60 \%$ of the lateral shoots browsed. Based on these data, the average percentage of browsed lateral shoots per tree on the respective field was calculated. We also measured the length of the young apical shoots. In case of browsing of an apical shoot, the topmost lateral shoot was marked in order to be able to continue apical shoot measurement in the next observation. The difference between the condition of the trees before and after grazing was considered to be damage caused by the cattle [29], since the fences prevented wild ungulates from entering. In order to evaluate the damage caused by wild ungulates during winter and spring, the results of the measurements, carried out as described above and made in autumn 2000 and repeated in June 2001 prior to the first cattle grazing, were compared.

The percentage of tree biomass gain or loss during defined grazing periods was calculated from the difference in the summarised lengths of the apical shoot and three lateral shoots of each tree measured after grazing compared to the shoot lengths before grazing, assuming that shoot length is closely correlated with biomass. In the case of the rowans, for biomass determination only the change of the apical shoot length was considered since, as mentioned above, no measurements were made in the lateral shoots.

The seedlings germinated in July after the first grazing were counted on 20 August 
2001 and the germination rate was calculated. After grazing the fields again for one week (21 to 28 August 2001), the remaining seedlings were counted and the percentage of seedlings surviving the second grazing period was calculated.

\subsection{Statistical evaluation}

Statistical analyses were performed with S-Plus, using the general linear model (GLM) procedure for analysis of variance [44]. This included herbage intake and digestibility data. The Tukey test was applied for multiple comparisons among means. In the case of not normally distributed data, pair-wise comparisons of means were performed with the Whitney-U-Test, and multiple comparisons among means were performed with the Kruskal-Wallis rank sum test. A contrast model was applied for the comparison of the data of the three grazed fields versus the data of the ungrazed field. Simple regression analysis was also carried out with S-Plus [44]. $P$-values $<0.05$ were considered as significant.

\section{RESULTS}

Most of the planted trees grew well. This was confirmed by the biomass gain of the T3 spruces, larches and rowans of 12, 4 and $21 \%$, respectively, on the control field during the 26 day lasting experiment. Only $4 \%$ of the $\mathrm{T} 2$ and $1 \%$ of the $\mathrm{T} 3$ trees dried up and died probably as a consequence of insufficient root-soil contact after planting. Additionally, $3 \%$ of the T2 and $2 \%$ of the T3 trees showed needle loss on some shoots. On average, the climate during the experiment was quite normal for this altitude according to the monthly weather reviews of MeteoSwiss [35]. The air temperature during the grazing experiment ranged from $0.2{ }^{\circ} \mathrm{C}$ to $20.8{ }^{\circ} \mathrm{C}$. The mean relative air humidity was $76 \%$, the mean radiation was $248 \mathrm{~W} \cdot \mathrm{m}^{-2}$ and the total precipitation was $164 \mathrm{~mm}$. In the first two weeks of the experiment, the temperature was higher than in other years [35]. At the end of the third week, it started raining $(37 \mathrm{~mm})$ which continued during the fourth week $(58 \mathrm{~mm})$. During that week, the mean air temperature was very low $\left(5.8^{\circ} \mathrm{C}\right)$.

\subsection{Feeding activity and feed quality}

On average, the heifers grazed almost half of the daytime (Tab. II). The animals spent more than one third of daytime under the canopy of mature trees. On average, the heifers spent $19 \%$ of their grazing time under the canopies of mature trees. There was no great difference in the activity of the heifers on the different fields. Space use and activity varied between the five daytimes investigated. In the early morning, in the afternoon and in the evening the main activity on the open pasture was grazing.

There were some differences between the herbage offered and that consumed. The herbage consumed contained somewhat less dry matter, more nitrogen and more fibre, differences which were quite consistent across all grazed fields (Tab. II). On average of the four weeks of grazing, the herbage collected from open pasture and from the forest area, respectively, contained $222 \pm 41$ and $213 \pm 47 \mathrm{~g} \mathrm{DM} \cdot \mathrm{kg}^{-1}$ wet weight and, per kg of DM, $929 \pm 5$ and $918 \pm$ $9 \mathrm{~g} \mathrm{OM}, 51 \pm 8$ and $48 \pm 10 \mathrm{~g}$ nitrogen, and $498 \pm 46$ and $502 \pm 34 \mathrm{~g} \mathrm{NDF}(\mathrm{n}=12$; data not given in the table).

On average, the heifers consumed $5.8 \mathrm{~kg}$ $\mathrm{DM} \cdot \mathrm{day}^{-1}$ (Tab. II) equivalent to $1.9 \pm$ $0.2 \mathrm{~kg} \mathrm{DM} \cdot 100 \mathrm{~kg}^{-1}$ live weight. Due to differing amounts of herbage available per hectare (Tab. I) at widely constant daily intakes, the time period until the utilisable herbage was consumed (14, 18 and 26 days) did not quite linearly increase with stocking density (3, 6 and 9 heifers). The apparent OM digestibility of the feed consumed on Field 2 was significantly lower than the coefficients found on the other fields (Tab. II). No other field differences in nutrient digestibilities occurred. 
Table II. Feeding and feed quality.

\begin{tabular}{|c|c|c|c|c|c|}
\hline & $\begin{array}{c}\text { Field } 0 \\
(0 \text { heifers })\end{array}$ & $\begin{array}{c}\text { Field } 1 \\
\text { (3 heifers) }\end{array}$ & $\begin{array}{c}\text { Field } 2 \\
\text { (6 heifers) }\end{array}$ & $\begin{array}{c}\text { Field } 3 \\
\text { (9 heifers) }\end{array}$ & $\begin{array}{c}\text { Field } \\
\text { effect }(P)\end{array}$ \\
\hline \multicolumn{6}{|l|}{ Grazing activity (\% of total time) } \\
\hline Complete area & & 46 & 44 & 43 & \\
\hline Under tree canopy & & 6 & 7 & 7 & \\
\hline Total time spent under tree canopy (\%) & & 33 & 36 & 34 & \\
\hline \multicolumn{6}{|l|}{ Nutrient composition } \\
\hline \multicolumn{6}{|l|}{ Dry matter (g. $\mathrm{kg}^{-1}$ wet weight) } \\
\hline - as offered & 203 & 251 & 228 & 228 & \\
\hline - as consumed & & 237 & 202 & 199 & \\
\hline \multicolumn{6}{|l|}{ Organic matter $\left(\mathrm{g} \cdot \mathrm{kg}^{-1} \mathrm{DM}\right)$} \\
\hline - as offered & 924 & 935 & 930 & 931 & \\
\hline - as consumed & & 934 & 934 & 931 & \\
\hline \multicolumn{6}{|l|}{ Nitrogen $\left(\mathrm{g} \cdot \mathrm{kg}^{-1} \mathrm{DM}\right)$} \\
\hline - as offered & 54 & 51 & 54 & 59 & \\
\hline - as consumed & & 62 & 59 & 62 & \\
\hline \multicolumn{6}{|l|}{ Neutral detergent fibre $\left(\mathrm{g} \cdot \mathrm{kg}^{-1} \mathrm{DM}\right)$} \\
\hline - as offered & 461 & 467 & 466 & 441 & \\
\hline - as consumed & & 481 & 479 & 475 & \\
\hline \multicolumn{6}{|l|}{ Feed intake 1} \\
\hline Dry matter intake $\left(\mathrm{kg} \cdot \mathrm{day}^{-1}\right)$ & & $6.3 \pm 0.1$ & $5.3 \pm 0.1$ & $5.8 \pm 1.4$ & 0.326 \\
\hline \multicolumn{6}{|l|}{ Apparent digestibility (\%) ${ }^{1}$} \\
\hline Organic matter & & $74.5^{\mathrm{a}} \pm 1.6$ & $71.1^{b} \pm 1.7$ & $73.7^{\mathrm{a}} \pm 1.5$ & 0.036 \\
\hline Nitrogen & & $71.2 \pm 2.4$ & $65.7 \pm 2.7$ & $69.7 \pm 0.7$ & 0.089 \\
\hline Neutral detergent fibre & & $69.7 \pm 1.8$ & $66.1 \pm 1.7$ & $68.3 \pm 2.1$ & 0.672 \\
\hline
\end{tabular}

a,b Field means lacking a common superscript differ at $P<0.05$.

1 (means \pm S.D.; $n=3)$.

\subsection{Germination of spruce seeds and survival of germinated seedlings}

On the grazed fields, there were significantly less seedlings found on plots under tree canopies than on the open pasture, which was mainly an effect of the differences occurring on Field 3 (Tab. III). There were trends to the highest germination rates in the ungrazed field (field effect: $P<0.05$ on total area and open pasture, and $P<0.1$ in the forest area; significant contrast of ungrazed vs. grazed open pasture). One week after the assessment, $48 \%$ of the germinated seedlings had survived on the control area. On the fields grazed in this week for the second time, on average $38 \%$ of the seedlings had survived this time, but the differences to the ungrazed field as well as the differences between forest area and open pasture remained insignificant. Due to high individual variation, the decline with increasing stocking densities of survival rates of 64 on Field 1 to 33 and $30 \%$ on Fields 2 and 3 was not significant.

\subsection{Browsing of saplings and young trees during winter and spring}

During winter and spring prior to the start of the cattle grazing period, $4 \%$ of the apical shoots of the T2 and $38 \%$ of the apical 
Table III. Germination of spruce seeds after different periods of first grazing and survival of these spruce seedlings (T1) after one week of second grazing in summer at different stocking densities.

\begin{tabular}{lcccccccc}
\hline & $n$ & $\begin{array}{c}\text { Field 0 } \\
(0 \text { heifers })\end{array}$ & $\begin{array}{c}\text { Field 1 } \\
(3 \text { heifers })\end{array}$ & $\begin{array}{c}\text { Field 2 } \\
(6 \text { heifers })\end{array}$ & $\begin{array}{c}\text { Field 3 } \\
(9 \text { heifers })\end{array}$ & $\begin{array}{c}\text { Mean of } \\
\text { grazed } \\
\text { fields }\end{array}$ & $\begin{array}{c}\text { Contrast } \\
\text { control to } \\
\text { grazed }\end{array}$ & $\begin{array}{c}\text { Field } \\
\text { effect } \\
(P)\end{array}$ \\
\hline $\begin{array}{l}\text { Seeds germinated }(\%) \\
\text { Total }\end{array}$ & & & & & & & & \\
Forest area & 8 & $6.4 \pm 4.5$ & $1.9 \pm 1.7$ & $2.0 \pm 3.3$ & $5.3 \pm 4.3$ & $3.0 \pm 1.9$ & 0.109 & 0.037 \\
Open pasture & 3 & $7.3 \pm 6.5$ & $2.6 \pm 1.7$ & $0.2 \pm 0.1$ & $1.3 \pm 1.4$ & $1.5 \pm 1.6$ & 0.885 & 0.096 \\
Seedlings survived $(\%)$ & 5 & $5.9 \pm 3.7$ & $1.4^{\mathrm{a}} \pm 1.7$ & $3.1^{\mathrm{ab}} \pm 3.9$ & $7 . \mathrm{b}^{*} \pm 3.6$ & $4.0^{*} \dagger \pm 4.0$ & 0.025 & 0.029 \\
Total & & & & & & & \\
Forest area & 8 & $48 \pm 26$ & $64 \pm 42$ & $33 \pm 17$ & $30 \pm 20$ & $38 \pm 19$ & 0.675 & 0.635 \\
Open pasture & 3 & $55 \pm 17$ & $72 \pm 48$ & 0 & $14 \pm 10$ & $55 \pm 39$ & 0.189 & 0.419 \\
\hline
\end{tabular}

a,b Field means lacking a common lower case superscript differ at $P<0.05$.

* Significantly different from the forest area at $P<0.05$.

$\dagger$ Significantly different from the ungrazed Field 0 at $P<0.05$ according to contrast analysis.

shoots of the T3 were browsed by wild ungulates (data not shown in table). The apical shoots of the rowans were browsed most severely by wild ungulates $(75 \%)$. The apical shoots of the T3 conifers, larch and spruce, were browsed at rates of 17 and $4 \%$, respectively. On average, 9, 6 and $8 \%$ of the lateral shoots of the young spruces, larches and rowans, respectively, were browsed by wild ungulates. The lateral shoots of the T2 spruces were not browsed during that period.

\subsection{Effects of cattle grazing on damage of spruce saplings}

There was no significant difference between forest area and open pasture in the browsing frequency of the T2 spruces (data not shown in the table). Apical and lateral shoot browsing on the T2 occurred most frequently on Field 1, which was grazed by the lowest number of cattle, and was apparently the lowest on Field 3 (Tab. IV; significant field effect in apical shoots after 7 days). On Field 3, the first browsing records on the T2 occurred after 7 (lateral shoots) and 14 days (apical shoot). Browsing of the T2 on Field 2 was also less severe than on Field 1 where finally almost every apical shoot and every fifth lateral shoot showed browsing damage. Trampling damage on the $\mathrm{T} 2$ did not occur until 14 days of grazing had passed, and remained low (0-11\%) from then on. At the end of the grazing experiment, $16 \%$ of the $\mathrm{T} 2$ spruces were lethally damaged by intense browsing or by rooting out.

\subsection{Effects of cattle grazing on damage of young trees}

On average of all fields, apical and lateral shoot browsing took place more frequently on T3 spruces than on T2 spruces (Tab. V). There was no significant difference in browsing frequency of the T3 spruces, larches and rowans between the forest area and open pasture (data not shown in table). On average of all fields, during the first two weeks of cattle grazing, the apical and lateral shoots of the T3 spruces were browsed significantly less intensively than those of the T3 larches and rowans. From the third week on, there was no significant difference anymore in the browsing of the three tree species. The apical shoot browsing of the T3 larches and rowans did not differ significantly during the whole grazing period. 
Table IV. Damage on Norway spruce (Picea abies (L.) Karst.) saplings (T2) by grazing (\% of total saplings on the respective field).

\begin{tabular}{|c|c|c|c|c|}
\hline & $\begin{array}{c}\text { Field } 1 \\
\text { (3 heifers) }\end{array}$ & $\begin{array}{c}\text { Field } 2 \\
\text { (6 heifers) }\end{array}$ & $\begin{array}{c}\text { Field } 3 \\
\text { (9 heifers) }\end{array}$ & Field effect $(P)^{1}$ \\
\hline \multicolumn{5}{|c|}{ Browsing on the apical shoot } \\
\hline after 3 days & 16 & 5 & 0 & 0.157 \\
\hline after 7 days & 26 & 10 & 0 & 0.048 \\
\hline after 14 days & 37 & 15 & 5 & 0.096 \\
\hline after 18 days & 47 & 30 & - & 0.518 \\
\hline after 26 days & 89 & - & - & - \\
\hline \multicolumn{5}{|c|}{ Browsing on lateral shoots ${ }^{2}$} \\
\hline after 3 days & 4 & 0 & 0 & 0.368 \\
\hline after 7 days & 12 & 1 & 5 & 0.191 \\
\hline after 14 days & 13 & 4 & 6 & 0.473 \\
\hline after 18 days & 18 & 8 & - & 0.695 \\
\hline after 26 days & 19 & - & - & - \\
\hline \multicolumn{5}{|c|}{ Trampling damage } \\
\hline after 3 days & 0 & 0 & 0 & - \\
\hline after 7 days & 0 & 0 & 0 & - \\
\hline after 14 days & 5 & 0 & 5 & 0.601 \\
\hline after 18 days & 5 & 0 & - & 0.344 \\
\hline after 26 days & 11 & - & - & - \\
\hline \multicolumn{5}{|c|}{ Lethally damaged trees ${ }^{3}$} \\
\hline after 3 days & 0 & 5 & 0 & 0.368 \\
\hline after 7 days & 5 & 5 & 5 & - \\
\hline after 14 days & 5 & 10 & 21 & 0.326 \\
\hline after 18 days & 5 & 10 & - & 0.574 \\
\hline after 26 days & 16 & - & - & - \\
\hline
\end{tabular}

${ }^{1} P$ value according to an evaluation with the Kruskal-Wallis rank sum test; after 18 days with the Whitney-U-Test.

${ }^{2}$ Average percentage of browsed lateral shoots per tree.

${ }^{3}$ By rooting out or by intense browsing.

When the herbaceous biomass had been totally exploited, the apical shoots were completely damaged (after 18 days in the T3 larches and rowans, after 26 days in the T3 spruces). Occasionally, there were significant field effects at distinct time points in browsing frequency, but a consistent trend to increased browsing frequency with increasing cattle number was found only in the larches. In the T3 larches, there were significant differences between the fields concerning the browsing frequency after 7 and 14 days. Lateral and apical shoot browsing showed similar trends with initially lower damage rates in the T3 spruces, and system- atic and significant field effects (after 7, 14 and 18 days) in the T3 larches. Generally, browsing on both apical and lateral shoots of the T3 clearly increased with grazing period at all livestock densities. Over all fields, browsing frequency (apical and lateral shoot browsing together) increased with grazing intensity (product of livestock units and grazing days), but linearly only in the T3 rowans and curvilinearly in the T3 larches (Fig. 1). There was only a weak linear relationship to grazing intensity in the T3 spruces, which was not significant. Trampling and breaking damage showed no systematic relationship to grazing period 
Table V. Damage on young trees (T3) of different species by grazing (\% of total young trees on the respective field $(\mathrm{F})$ ).

\begin{tabular}{|c|c|c|c|c|c|c|c|c|c|c|c|c|}
\hline \multirow{3}{*}{$\begin{array}{l}\text { Fields } \\
\text { Heifers }\end{array}$} & \multicolumn{4}{|c|}{ Norway spruces } & \multicolumn{4}{|c|}{ European larches } & \multicolumn{4}{|c|}{ Rowans } \\
\hline & F1 & $\mathrm{F} 2$ & F3 & & $\mathrm{F} 1$ & $\mathrm{~F} 2$ & F3 & & $\mathrm{F} 1$ & $\mathrm{~F} 2$ & F3 & \\
\hline & 3 & 6 & 9 & $P^{1}$ & 3 & 6 & 9 & $P$ & 3 & 6 & 9 & $P$ \\
\hline \multicolumn{13}{|c|}{ Browsing on the apical shoot ${ }^{2}$} \\
\hline after 3 days & 28 & 0 & 0 & 0.005 & 11 & 50 & 33 & 0.044 & 33 & 72 & 33 & 0.028 \\
\hline after 7 days & 39 & 6 & 33 & 0.082 & 11 & 67 & 89 & 0.001 & 56 & 100 & 56 & 0.055 \\
\hline after 14 days & 61 & 11 & 56 & 0.020 & 22 & 100 & 111 & 0.001 & 89 & 111 & 67 & 0.176 \\
\hline after 18 days & 89 & 67 & - & 0.403 & 94 & 128 & - & 0.098 & 100 & 128 & - & 0.396 \\
\hline after 26 days & 111 & - & - & - & 106 & - & - & - & 106 & - & - & - \\
\hline \multicolumn{13}{|c|}{ Browsing on lateral shoots ${ }^{3}$} \\
\hline after 3 days & 4 & 1 & 0 & 0.152 & 3 & 11 & 6 & 0.077 & 21 & 19 & 16 & 0.800 \\
\hline after 7 days & 7 & 4 & 13 & 0.038 & 7 & 16 & 28 & 0.048 & 34 & 30 & 28 & 0.971 \\
\hline after 14 days & 13 & 7 & 41 & 0.001 & 20 & 34 & 48 & 0.014 & 43 & 40 & 32 & 0.716 \\
\hline after 18 days & 36 & 47 & - & 0.168 & 46 & 52 & - & 0.662 & 50 & 51 & - & 0.987 \\
\hline after 26 days & 63 & - & - & - & 48 & - & - & - & 52 & - & - & - \\
\hline \multicolumn{13}{|c|}{ Trampling damage } \\
\hline after 3 days & 0 & 6 & 0 & 0.368 & 6 & 0 & 0 & 0.368 & 0 & 0 & 0 & - \\
\hline after 7 days & 0 & 6 & 0 & 0.368 & 11 & 0 & 0 & 0.130 & 0 & 0 & 0 & - \\
\hline after 14 days & 6 & 6 & 0 & 0.601 & 17 & 6 & 6 & 0.421 & 0 & 0 & 0 & - \\
\hline after 18 days & 6 & 6 & - & - & 22 & 17 & - & 0.961 & 0 & 6 & - & 0.345 \\
\hline after 26 days & 6 & - & - & - & 28 & - & - & - & 0 & - & - & - \\
\hline \multicolumn{13}{|c|}{ Breaking of lateral shoots } \\
\hline after 3 days & 0 & 0 & 0 & - & 0 & 6 & 0 & 0.368 & 0 & 0 & 0 & - \\
\hline after 7 days & 0 & 0 & 0 & - & 0 & 6 & 6 & 0.601 & 11 & 11 & 6 & 0.806 \\
\hline after 14 days & 11 & 6 & 0 & 0.345 & 0 & 22 & 17 & 0.123 & 11 & 11 & 6 & 0.806 \\
\hline after 18 days & 11 & 17 & - & 0.654 & 11 & 22 & - & 0.391 & 11 & 11 & - & - \\
\hline after 26 days & 11 & - & - & - & 11 & - & - & - & 11 & - & - & - \\
\hline \multicolumn{13}{|c|}{ Lethally damaged trees ${ }^{4}$} \\
\hline after 3 days & 0 & 0 & 0 & - & 0 & 0 & 0 & - & 0 & 0 & 0 & - \\
\hline after 7 days & 0 & 0 & 0 & - & 17 & 0 & 0 & 0.044 & 6 & 0 & 0 & 0.368 \\
\hline after 14 days & 0 & 0 & 0 & - & 17 & 0 & 11 & 0.220 & 6 & 0 & 6 & 0.601 \\
\hline after 18 days & 0 & 0 & - & - & 17 & 0 & - & 0.080 & 6 & 0 & - & 0.345 \\
\hline after 26 days & 0 & - & - & - & 22 & - & - & - & 6 & - & - & - \\
\hline
\end{tabular}

${ }^{1} P$ value testing the significance of differences between F1, F2 and F3, according to an evaluation with the Kruskal-Wallis rank sum test; after 18 days with the Whitney-U-Test.

2 Values exceeding $100 \%$ are possible because a new apical shoot was marked when the first marked shoot had been browsed.

${ }^{3}$ Average percentage of browsed lateral shoots per tree on the respective field.

${ }^{4}$ By rooting out or by intense browsing. 


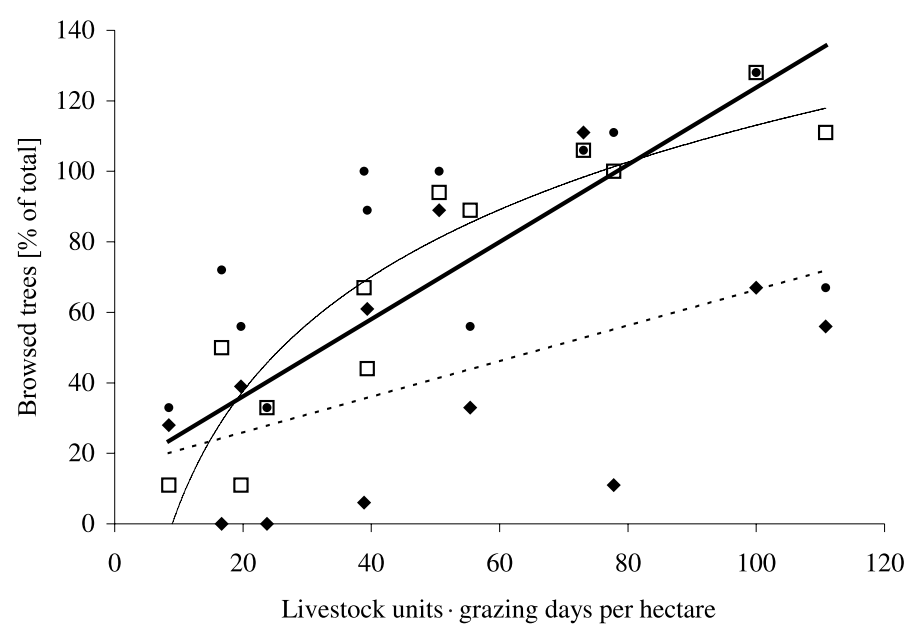

Figure 1. Regression of apical shoot browsing of $\mathrm{T} 3$ trees (y) on grazing intensity described by the product of livestock units $\cdot$ grazing days $(\mathrm{x})$.

- ....., Norway spruce (Picea abies (L.) Karst): $\mathrm{y}=0.507 \mathrm{x}+15.78, \mathrm{R}^{2}=0.22, P=0.123$;

$\square, \ldots$, European larch (Larix decidua Miller): $\mathrm{y}=1.095 \mathrm{x}+14.26, \mathrm{R}^{2}=0.83, P<0.0001$;

$\bullet,-$, Rowan (Sorbus aucuparia L.): $\mathrm{y}=46.90 \ln (\mathrm{x})-102.87 ; \mathrm{R}^{2}=0.85 ; P=0.043$.

and stocking density (Tab. V), except for the increasing percentage of trampled $\mathrm{T} 3$ larches on Field 1 with increasing times of grazing. None of the T3 spruces died during the experiment due to damage caused by cattle and only $4 \%$ of the T3 rowans died due to intense browsing. On average of all grazed fields, $11 \%$ of the T3 larches were lethally damaged.

The biomass change of the young trees, as estimated from the variation of the lengths of the apical and lateral shoots, is an indicator of the intensity of browsing damage on young trees. While the trees on the ungrazed field successively gained biomass, the browsed trees on the grazed fields lost biomass, and this increasingly with higher grazing intensity (product of stocking density and grazing period; Fig. 2). However, the biomass loss differed between tree species and was significant for the larches only. During week 1 of grazing, there was no loss of spruce biomass at all, and it remained relatively low during the whole grazing period. By contrast, the larches lost much biomass due to browsing. Although the rowans were browsed intensively, they showed only little loss of biomass or even biomass increment, since they re-sprouted rapidly after being browsed. At the end of the grazing period, the average calculated biomass loss of $\mathrm{T} 3$ reached one third, one fourth and one fifth on Fields 1, 2 and 3 , respectively.

\section{DISCUSSION}

\subsection{Effect of stocking density on feeding and feed quality}

Apart from the basic effect of a linearly increasing grazing pressure with the number of heifers, possibly associated changes in grazing behaviour, spatial use pattern (trampling and browsing probability), intake and quality of the feed consumed (together determining the coverage of nutrient requirements) may affect seed germination and tree damages. There are several driving forces determining the space use and activity of 


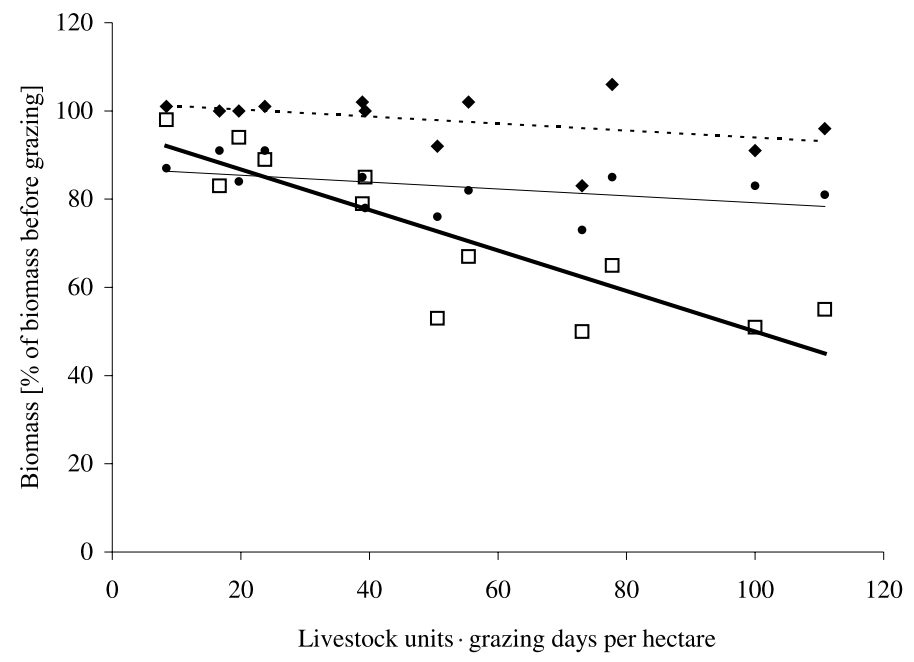

Figure 2. Regression of biomass development of T3 trees (estimated as the summarised shoot lengths; \% of initial) (y) on grazing intensity described by the product of livestock units · grazing days $(\mathrm{x})$.

......, Norway spruce (Picea abies (L.) Karst): $\mathrm{y}=-0.0796 \mathrm{x}+101.91 ; \mathrm{R}^{2}=0.1, P=0.175$;

$\square, \ldots$, European larch (Larix decidua Miller): $\mathrm{y}=-0.4596 \mathrm{x}+95.951 ; \mathrm{R}^{2}=0.75, P<0.0001$;

$\bullet,-$, Rowan (Sorbus aucuparia $\mathrm{L}$.): $\mathrm{y}=-0.0778 \mathrm{x}+86.981 ; \mathrm{R}^{2}=0.22 ; P=0.122$.

cattle on pasture. Stuth [46] gives the following hierarchy of physiological needs of large grazers (in order of decreasing importance): thirst, warmth/coolness, hunger, night, rest. The heifers in our experiment were grazing almost half of the daytime. As in another study [21], the main grazing activity was observed in the early morning, in the late afternoon and in the evening. Lactating cows receiving no concentrate were observed to graze until complete darkness in order to cover nutrient requirements while supplemented cows stopped grazing much earlier in the day [4]. The heifers in our experiment, having far lower requirements, consequently needed a considerably shorter time period for grazing than the dairy cows even in the situation of a high grazing pressure. The heifers spent one third of the time in the area covered by the canopies of old trees, which made up only $20 \%$ of the total area, but this time was predominantly used for resting as reported elsewhere [42], which is explained by the importance of trees as a shelter against wind, cold, precipitation and solar radiation $[11,12,16]$. Since heifers nevertheless were found to intensively graze the forest area (on average, 6 to $7 \%$ of the total grazing time), particularly in the first week of grazing, this study contradicts the assumption of Troxler [48] that cattle generally avoid grazing in the forest before all the herbage on the open area had been exploited. Also Putman [42] found that cattle prefer open areas for grazing. The present study, different from what was expected from other assumptions [1], showed virtually no differences in quality between the herbage growing under tree canopy and on the open pasture. This could have been due to the fact that the trees, except those deliberately planted for the experiment, were old and high. However, since herbage biomass grown under the shade of the tree canopy was less dense, these feed resources were mostly spent after one week of grazing. There were no noticeable differences in space use and activity pattern among the fields. 
The herbage intake measured was as high as expected for heifers of that live weight and age [49], and the level of intake did not differ significantly between the fields although the herbage amounts offered per animal differed substantially. The herbage consumed had higher $\mathrm{N}$ contents than the herbage offered, suggesting a selection for $\mathrm{N}$ which, however, was not found to be a major driving force on other nutrient-poor montane pastures [5]. An effect of stocking density on selection for $\mathrm{N}$ is also not likely since urine $\mathrm{N}$ concentration (data not shown in the table) was not affected by the fields. The few field effects in OM and fibre digestibility were not systematic in terms of stocking density but may reflect involuntary differences in species composition of herbage between Field 2 on the one hand and Fields 1 and 3 on the other hand. In summary, foraging behaviour and nutrient intake did not differ much among stocking densities and therefore are not considered to be major explanatory factors for tree damage.

\subsection{Germination of spruce seeds as depending on cattle grazing}

Based on the results of Stöckli et al. [45], a positive influence of grazing cattle on the germination of spruce seeds was expected, which would even increase with higher stocking density. The underlying hypothesis is that trampling of the animals could reduce the vigour of the herbaceous vegetation [27], remove part of the organic layer and uncover the mineral layer of the soil [6], thus facilitating tree germination. In the present experiment, however, more seedlings were found on the ungrazed field than on most grazed fields, although on the open pasture of Field 3, which was grazed at the highest stocking density but until 8 July only, significantly more seedlings were found than on the control field. In other seeding experiments in subalpine forests [6, 23 ], spruce seedlings started to germinate in the first half of July, and after heavy rainfalls only $\left(>10 \mathrm{~mm} \cdot \mathrm{day}^{-1}\right)$. In our experiment, rainfalls of more than $10 \mathrm{~mm}$ were measured on days 4, 13, 21, 22, 24 and 26.
Thus, the cause for the low number of spruce seedlings found on Fields 1 and 2, which was grazed at the lowest stocking density but for the longest period, might be that seedlings which already started to germinate during the grazing period might have been trampled on or eaten by the cattle. This is known for wild ungulates [39]. Miller et al. [36], however, found that small seedlings can be browsed if growing on bare ground only, but otherwise they may not be damaged until they have grown above the surrounding vegetation. Also in the experiments of Kullberg and Bergström [25], shorter seedlings were less often selected than taller ones. Bergström and Bergquist [3] found more browsing on 2-year-old than on 1-year-old spruce seedlings. Concerning the small difference between germination on the grazed fields and the control field, one has to take into account that the soil of all fields, including the control, had been influenced by grazing in the years before, thus only very intensive grazing during the experiment could have had an obvious additional influence on the germination rate of the spruce seeds. On the open pasture, more seedlings were found than under mature trees. This is in accordance with the findings of Trepp [47] that in the subalpine stage, tree regeneration usually grows on small gaps in the forest and not directly under the canopy of mature trees.

\subsection{Browsing and other damage to seedlings, saplings and young trees by cattle}

Tree damage during periods of grazing with different stocking densities was investigated in the present study in recently germinated spruce seedlings (during secondary grazing of one week only), spruce saplings of $14 \mathrm{~cm}$ height (T2) and young spruces, larches and rowans of $42 \mathrm{~cm}$ height (T3, during grazing for different periods). In the $\mathrm{T} 2$ and $\mathrm{T} 3$, browsing damage was differentiated from other damage. Overall, the results show that there was a relationship between the frequency of tree damage and 
grazing intensity, as given by stocking density and the length of the grazing period, which supports the findings of Pitt et al. [40]. However, the two components of grazing intensity appear to differ in their effect on different tree species and between trees of different age. Additionally, factors apart from grazing intensity, e.g. deviant foraging behaviour of certain animals participating in the experiment and previous browsing of the trees by wild ungulates, which might have caused changes in the chemical characteristics of the browsed trees [10], played an important role in some occasions. Generally, the extent of tree damage was high compared to that found in previous studies on established wood pastures where damage frequency of single grazing periods mostly did not exceed $9 \%$ of all trees [32].

The percentage of seedlings that survived grazing tended to be the highest on Field 1, which was grazed at the lowest stocking density. Also Hester et al. [19] who studied trampling and browsing by sheep, found that the frequency of trampling and browsing on seedlings increased with the stocking density. On montane wood pastures, Spatz and Rösch [43] found some trampling of seedlings but the damage was not considered to be severe. Unexpectedly, the survival rate of the seedlings germinated on the ungrazed field was not significantly higher than that on the grazed fields but, taking into account the higher mean germination rate on this field, the final number of survived seedlings was the highest nevertheless. There might be other factors affecting differently the survival of germinated tree seedlings in the presence or absence of grazing, such as the shadowing herbaceous vegetation that was undisturbed in growth on the ungrazed field. The survival of seedlings of forest trees is known to be reduced by physical or chemical competition [2]. Additionally, previous grazing of the ungrazed fields might have provoked an unusually high growth rate of the herbaceous vegetation, compared to long-term ungrazed fields.
Due to an accumulation of damage, in T2 and $\mathrm{T} 3$, the percentage of browsing damage increased with the length of the grazing period on all fields, more or less linearly. However, this also means that, with few exceptions, there was no clear increase in browsing frequency when herbage was getting scarcer with a progressing grazing period. The situation was far less clear in terms of actual stocking density, where there were contrasting effects on browsing frequency in different tree species when compared after the same period of grazing. There are three different main reasons for browsing: (i) accidental browsing [29], e.g. when tree parts are covered by herbage (more likely in saplings than in young trees), (ii) utilisation of tree parts as a nutrient source and (iii) deliberate browsing of trees for curiosity reasons or because of boredom. On established wood pastures that are grazed at lower stocking densities and where browsing frequency is generally low [32], the first form seems to be the main reason for browsing. When grazing is extended until herbage gets scarce, the probability of browsing on less palatable plants increases [18]. This could include tree parts, although young conifer trees would never provide sufficient nutritious biomass for a substantial prolongation of the grazing period. Finally, there could be individual differences in the extent to which animals experiment with feed sources that they are not used to. Occasionally, certain animals may develop a specific preference for shoots, leaves or needles of certain trees.

The results of the present study suggest that tree species could be classified for their tendency to be browsed for a certain type of reason. Apical and lateral shoots of T3 rowans and larches appear to have suffered from being used as a feed source and therefore these damages depended on stocking density and overall grazing intensity (product of grazing days and livestock units per hectare). A preference of cattle to browse rowan was also observed in our previous studies on established wood pastures [32]. In contrast, sheep tend to browse rowan at 
the seedling stage only [19]. Also wild ungulates browse rowan intensively [20, 37, 38]. Kullman [26] found browsing by wild ungulates on $78 \%$ of the rowans on transects in Swedish subalpine forests. In experiments of Spatz and Rösch [43] on montane wood pastures, rowan was the only tree species that was browsed by cattle. The traditional use of rowan for tree pollarding and leaf-hay production [17] demonstrates the feed potential of this tree species and therefore explains the preference of livestock for broad-leafed trees. However, only $4 \%$ of the rowans in our experiment died due to intense browsing as the others immediately started to re-sprout after they had been browsed. This characteristic might explain the low biomass loss of the rowans despite the intense shoot browsing. Larches were especially browsed at the end of the grazing period in the present experiment, resulting in the biggest biomass losses of all tree species investigated and in the lowest survival rate. This may partly be explained by the lower growth speed of the larches compared to spruces and rowans, thus resulting in a slower compensation of the biomass loss directly after browsing. However, Pollanschütz [41] emphasises that larches are more tolerant to browsing damage than other tree species. This implies that the larches might compensate for the biomass loss due to browsing in the subsequent growing seasons, if the fields are grazed at lower stocking densities. During our own studies on established wood pastures grazed at a stocking density of $0.4 \mathrm{LU} \cdot \mathrm{ha}^{-1}$, no single larch was browsed by cattle [31]. An important reason for the larches of the present study to be used as a nutrient source could have been their origin from a tree nursery located on a lower altitude where the soil contains more nutrients. These trees could, therefore, have been more nutritious than larches of natural regeneration and could have served for the heifers to supplement the increasingly $\mathrm{N}$ depleted herbage. This is a common phenomenon in browsing of wildlife [34].
The T2 and T3 spruces, in contrast to the T3 larches and rowans, were browsed most intensively on Field 1 (with the lowest stocking density). On that field, according to the observations, most browsing was caused by one individual animal, which obviously had developed a preference for spruce needles. Since the heifers spent their first summer on a subalpine pasture and there were no adult cattle present to be imitated, the heifers had to find out by themselves which plant species were palatable. Experimenting as the assumed major reason for spruce browsing is confirmed by the known aversion of most cattle against using spruce shoots as forage [22]. Experimenting might also have been the reason for lethally damaging some $\mathrm{T} 2$ spruces by rooting out. According to Bergström and Bergquist [3], bare-rooted saplings might be more susceptible to rooting out than containerised ones. Apical and lateral shoot browsing, however, was found more frequently on $\mathrm{T} 3$ spruces than on $\mathrm{T} 2$ spruces. This supports the results of Bergström and Bergquist [3] and Kullberg and Bergström [25] that shorter trees were less often selected than taller ones. None of the taller young spruces died due to browsing by cattle. Also North American conifers, such as the Douglas fir (Pseudotsugamentiesii), are not prone to be browsed by cattle [24]. On large fields that are grazed at low stocking densities cattle may be occupied with selecting the most palatable and digestible herbage, thus being in move and having enough diversion [31]. This indicates difficulties in simulating the effect of grazing intensity on small fields and may have masked an underlying relationship between grazing intensity and spruce browsing as described earlier [32].

Trampling scars were not very often found in the beginning but became more frequent at the end of the grazing period. Spatz and Rösch [43] found trampling scars on $10 \%$ of all young spruces after intensive cattle grazing on a montane wood pasture. In our previous comparative field studies on established wood pastures, we found few 
trees with trampling scars [32]. Cattle seem to actively avoid trampling of young trees and, additionally, young trees are very flexible thus being relatively resistant against damage by the claws of the cattle [43]. In the present study, larches were most susceptible to damage by the breaking of lateral shoots as another form of damage caused by trampling but also by browsing. Different from the spruces and the rowans, the planted young larches had very fragile shoots probably as a consequence of faster growth in the nursery than when growing in the forest. Playing with and pulling on the yellow marks of adhesive tape used for marking the sample trees, which was observed as one reason for breaking damage, therefore affected the larches more than the other young trees. There was no clear influence of stocking density on trampling and breaking damage of saplings and young trees suggesting that also here individual behavioural patterns were the most decisive.

In our previous own dendroecological studies on established wood pastures [30], we found that the number of young trees $<3 \mathrm{~m}$ in grazed forests is somewhat lower, but the percentage of larches is higher and the trees grow faster than in ungrazed forests, probably due to the better light conditions as a consequence of the lower density of the forest stand. However, this might not only be due to the browsing and trampling of the cattle but also due to the felling of both mature and young trees by the farmers in order to improve the growing conditions for the herbage.

\section{CONCLUSIONS}

The actual stocking densities per day realised in the experiment exceeded those mostly imposed on established subalpine wood pastures, except for the quite frequent situations where a short-term grazing of wood pastures is applied as part of a system relying more on pastures situated above the tree line. Seen over the complete growing season, the grazing pressure was therefore not excessively high (1.2 LU.ha ${ }^{-1}$ at most).
By grazing the fields until the herbage was totally exploited, the expression of grazing effects on the experimental trees was further facilitated. As expected from our own observations on established wood pastures, the broad-leafed tree rowan was browsed frequently and severely, while the cause for the high browsing frequency of the planted larches might have been their origin from tree nurseries. There is plenty of evidence that elevated levels of nitrogen in foliage will increase a tree's susceptibility to browsing [14, 34]. Further studies on naturally regenerated larches are therefore necessary. The relationship between spruce browsing and stocking density as well as grazing period was probably masked by the experimenting activities of individual animals. The lack of any natural tree regeneration on the experimental site, which has been intensively grazed for decades, furthermore illustrates previous recommendations [32] to restrict stocking density and length of the grazing period in order to manage the wood pastures in a sustainable way. However, our own studies on established wood pastures suggest that the landowners also play an important role in the management of wood pastures, since thinning of the forest improves the growing conditions for both the forest regeneration and the herbage biomass production. At the beginning of the grazing period, the intensive observation of the cattle herds by the farmers is recommended in order to detect the animals that have developed a specific preference for tree browsing. By removing such individuals from the cattle herd, the extent of browsing on young trees could be limited. To alleviate these problems, heifers might also be grazed together with experienced cattle for the first summer. Thus, they can imitate the herbage selection pattern of the experienced cattle and do not rely on experimenting with the different forage plant species.

\section{ACKNOWLEDGEMENTS}

We are grateful to Dr. H. Leuenberger his staff for their assistance in the experiment at the 
ETH research station Weissenstein. We are also grateful to C. Kunz and S. Ayra for the precise laboratory work and G. Zosso for the preparation of the résumé. This study was supported by a grant of the VELUX foundation, Glarus, Switzerland, and was performed within the polyproject PRIMALP (Sustainable Primary Production in the Alpine Region) of ETHZurich.

\section{REFERENCES}

[1] Bailey D.W., Daily selection of feeding areas by cattle in homogeneous and heterogeneous environments, Appl. Anim. Behav. Sci. 45 (1995) 183-200

[2] Benayas J.M.R., Espigares T., Castro-Diez P., Simulated effects of herb competition on planted Quercus faginea seedlings in Mediterranean abandoned cropland, Appl. Veg. Sci. 6 (2003) 213-222.

[3] Bergström R., Bergquist G., Large herbivore browsing on conifer seedlings related to seedling morphology, Scand. J. Forest Res. 14 (1999) 361-367.

[4] Berry N.R., Sutter F., Bruckmaier R., Blum J., Kreuzer M., Limitations of high-alpine grazing conditions for early-lactation cows: effects of energy and protein supplementation, Anim. Sci. 73 (2001) 149-162.

[5] Berry N.R., Jewell P.L., Sutter F., Edwards P.J., Kreuzer M., Selection, intake and excretion of nutrients by Scottish highland suckler beef cows and calves, and Brown Swiss dairy cows in contrasting alpine grazing systems, $\mathbf{J}$. Agr. Sci. (Camb.) 139 (2002) 437-453.

[6] Brang P., Experimentelle Untersuchungen zur Ansamung der Fichte im zwischenalpinen Gebirgswald, Schweizerische Zeitschrift für Forstwesen (Special Issue) 77 (1996) 375.

[7] Brassel P., Brändli U.-B. (Eds.), Schweizerisches Landesforstinventar. Ergebnisse der Zweitaufnahme 1993-1995, Birmensdorf, Eidgenössische Forschungsanstalt für Wald, Schnee und Landschaft, Bern, Bundesamt für Umwelt, Wald und Landschaft ed. Haupt, Berne, Stuttgart, Vienna, 1999, p. 442.

[8] Delucchi M., Waldweide aus forstlicher Sicht, Bündner Wald 46. Jahrgang (1993) 12-15.

[9] Dietl W., Berger P., Ofner M., Die Kartierung des Pflanzenstandortes und der futterbaulichen Nutzungseignung von Naturwiesen, Eidg. Forschungsanstalt für landwirtschaftlichen Pflanzenbau und Arbeitsgemeinschaft zur Förderung des Futterbaues, Zürich-Reckenholz, Switzerland, 1981.

[10] Duncan A.J., Hartley S.E., Iason G.R., The effect of previous browsing damage on the morphology and chemical composition of
Sitka spruce (Picea sitchensis) saplings and on their subsequent susceptibility to browsing by red deer (Cervus elaphus), Forest Ecol. Manag. 103 (1998) 57-67.

[11] Elmer R., Wald-Weide-Ausscheidung aus landwirtschaftlicher Sicht, Bündner Wald 46, Jahrgang (1993) 16-23.

[12] Estermann B.L., Wettstein H.-R., Sutter F., Kreuzer M., Nutrient and energy conversion of grass-fed dairy and suckler beef cattle kept indoors or on high altitude pasture, Anim. Res. 50 (2001) 477-493.

[13] Etienne M.H., Western Europe silvopastoral systems, INRA Editions, 1996, p. 275.

[14] Gill R.M.A., A review of damage by mammals in north temperate forests: 3 . Impact on trees and forests, Forestry 65 (1992) 145-169.

[15] Gillet F., Gallandat J.D., Wooded pastures of the Jura mountains, in: Etienne M. (Ed.), Western European Silvopastoral Systems, Paris, 1996, pp. 37-54.

[16] Gillet F., Organisation et dynamique du système pâturage boisé, in: Le pâturage boisé : quel avenir? Bulletin der Schweizerischen Gesellschaft für Pflanzenbauwissenschaften, Zurich-Reckenholz, Switzerland, 10, 1998, p. 12.

[17] Haas J.N., 6000 years of tree pollarding and leaf-hay foddering in the Alpine area, Aust. J. Forest Sci. (2003) 231-240.

[18] Haeggström C.A., The influence of sheep and cattle grazing on wooded meadows in Aland, SW Finland, Acta Bot. Fenn. 141 (1990) 128.

[19] Hester A.J., Mitchell F.J.G., Kirby K.J., Effects of season and intensity of sheep grazing on tree regeneration in a British upland woodland, Forest Ecol. Manag. 88 (1996) 99106.

[20] Homolka M., Heroldova M., Impact of large herbivores on mountain forest stands in the Beskydy Mountains, Forest Ecol. Manag. 181 (2003) 119-129.

[21] Howery L.D., Provenza F.D., Banner R.E., Scott C.B., Differences in home range and habitat use among individuals in a cattle herd, Appl. Anim. Behav. Sci. 49 (1996) 305-320.

[22] Huntsinger L., Grazing in a California silvopastoral system: effects of defoliation season, intensity, and frequency on deerbrush, Ceanothus integerrimus, Agroforestry Syst. 34 (1996) 67-82.

[23] Imbeck H., Ott E., Verjüngungsökologische Untersuchungen in einem hochstaudenreichen subalpinen Fichtenwald, mit spezieller Berücksichtigung der Schneeablagerung und der Lawinenbildung, Mitteilungen des 
Eidgenössischen Instituts für Schnee- und Lawinenforschung Davos 42 (1987) 202.

[24] Krueger W.C., Cattle grazing in managed forests, in: Roché B.F., Baumgartner D.M. (Eds.), Forestland Grazing, Washington State University, Pullman, Washington, USA, 1983, pp. 29-42.

[25] Kullberg Y., Bergström R., Winter browsing by large herbivores on planted deciduous seedlings in southern Sweden, Scand. J. Forest Res. 16 (2001) 371-378.

[26] Kullman L., Temporal and spatial aspects of subalpine populations of Sorbus aucuparia in Sweden, Ann. Bot. Fenn. 23 (1986) 267-275.

[27] Linhart Y.B., Whelan R.J., Woodland regeneration in relation to grazing and fencing in Coed Gorswen, North Wales, J. Appl. Ecol. 17 (1980) 827-840.

[28] Liss B.-M., Der Einfluss von Weidevieh und Wild auf die natürliche und künstliche Verjüngung im Bergmischwald der ostbayerischen Alpen, Forstwissenschaftliches Centralblatt 107 (1988) 14-25.

[29] Liss B.-M., Versuche zur Waldweide - Der Einfluss von Weidevieh und Wild auf Verjüngung, Bodenvegetation und Boden im Bergmischwald der ostbayerischen Alpen, Forstliche Forschungsberichte München, Schriftenreihe der Forstwissenschaftlichen Fakultät der Universität München und der Bayerischen Forstlichen Versuchs- und Forschungsanstalt, Munich, Germany, 87, 1988, p. 209.

[30] Mayer A.C., Stöckli V., Long-term influence of livestock grazing on the structure of subalpine forests, Arctic, Antarctic Alpine Res. (2005) in press.

[31] Mayer A.C., Stöckli V., Konold W., Kreuzer M., Influence of cattle stocking rate on browsing of Norway spruce in subalpine wood pastures, Agroforestry Syst. (2005) in press.

[32] Mayer A.C., Stöckli V., Konold W., Estermann B.L., Kreuzer M., Effects of grazing cattle on subalpine forests, in: Bottarin R., Tappeiner U. (Eds.), Interdisciplinary Mountain Research, Blackwell Verlag GmbH, Berlin, Wien, 2002, pp. 208-218.

[33] Mayer A.C., Stöckli V., Huovinen C., Konold W., Estermann B.L., Kreuzer M., Herbage selection by cattle on sub-alpine wood pastures, Forest Ecol. Manag. 181 (2003) 39-50.

[34] McArthur C., Marsh N.R., Close D.C., Walsh A., Paterson S., Fitzgerald H., Davies N.W., Nursery conditions affect seedling chemistry, morphology and herbivore preferences for Eucalyptus nitens, Forest Ecol. Manag. 176 (2003) 585-594.

[35] MeteoSwiss, Monthly Weather Review, June, July and August 2001, Zurich, 2002.
[36] Miller G.R., Kinnaird J.W., Cummins R.P., Liability of saplings to browsing on a red deer range in the Scottish Highlands, J. Appl. Ecol. 19 (1982) 941-951.

[37] Motta R., Ungulate impact on rowan (Sorbus aucuparia L.) and Norway spruce (Picea abies (L.) Karst.) height structure in mountain forests in the eastern Italian Alps, Forest Ecol. Manag. 181 (2003) 139-150.

[38] Ott E., Frehner M., Frey H.-U., Lüscher P., Gebirgsnadelwälder, Ein praxisorientierter Leitfaden für eine standortgerechte Waldbehandlung, Paul Haupt ed., 1997, p. 288.

[39] Palmer S.C.F., Mitchell R.J., Truscott A.M., Welch D., Regeneration failure in Atlantic oakwoods: the roles of ungulate grazing and invertebrates, Forest Ecol. Manag. 192 (2004) 251-265.

[40] Pitt M.D., Newman R.F., Youwe P.L., Wikeem B.M., Quinton D.A., Using a grazing pressure index to predict cattle damage of regenerating tree seedlings, J. Range Manag. 51 (1998) 417-422.

[41] Pollanschütz J., Bewertung von Verbiss- und Fegeschäden, Mitteilungen der Forstlichen Bundesversuchsanstalt Wien, Austria, 169, 1995, p. 99.

[42] Putman R.J., Grazing in temperate ecosystems. Large herbivores and the ecology of the New Forest, Portland, Timber Press, 1986, p. 207.

[43] Spatz G., Rösch K., Der Einfluss von Wild und Weidevieh auf die Naturverjüngung des Bergwaldes, Alm- und Bergbauer 11 (1990) 120-130.

[44] SPSS Inc., SYSTAT 6.0 for Windows, Statistics, Chicago, USA, 1996.

[45] Stöckli V., Pfister R., Frey W., Erforschung der Wechselwirkung zwischen Schutzwald und Lawinen, Schweizer Wald 11 (1997) 1417 .

[46] Stuth J.W., Foraging behavior, in: Heitschmidt R.K., Stuth J.W. (Eds.), Grazing Management: an Ecological Perspective, Wilshire, Oregon, 1996, pp. 65-84.

[47] Trepp W., Das Besondere des Plenterns im Gebirgswald, Schweizerische Zeitschrift für Forstwesen 132 (1981) 823-846.

[48] Troxler J., Landwirtschaftlicher Nutzwert und Tierverhalten, in: Le paturage boisé : quel avenir ? Bulletin der Schweizerischen Gesellschaft für Pflanzenbauwissenschaften, ZurichReckenholz, Switzerland, 10, 1998, p. 11.

[49] Wettstein H.-R., Estermann B.L., Kreuzer M., Comparison of feed intake and nitrogen turnover of suckler beef and heifers on sub-alpine and alpine pastures, Proc. Soc. Nutr. Physiol. 11 (2002) 145. 